\title{
PATTERN OF PESANTREN ON EXPANDING OF SMART, HARDWORKING AND IKHLAS CHARACTERS IN WEST SUMATERA
}

\author{
Firdaus, Ismail Suardi Wekke \\ Sekolah Tinggi Keguruan \& ilmu Pendidikan (STKIP) PGRI Sumatera Barat, \\ Indonesia. \\ Sekolah Tinggi Agama Islam Negeri (STAIN) Sorong, West Papua, Indonesia
}

\begin{abstract}
The objective of education is to sharpen the intelligence, strengthening the will, and soften feelings indeed. However, in fact the result of education process can not achieved educational goals. In everyday life, we still found that educated people are not smart, quitter and abrasive heart. Corruption, murder, sexual abuse and other immoral behavior continued carried out by educated people throughout the day. Some of that immoral behavior even carried out by a teacher. Many studies have been done to answer why education does not change people to behave like an educated person. The studies discuss the majority practice is that the character building process of students in the learning process, it caused many studies offer the model of character building in learning processes at school. Among the study, not many offer formation of smart, hardworking and ikhlas characters model at pesantren in West Sumatra. This article explores patterns of pesantren educational system to construct smart, hardworking and ikhlas characters in West Sumatera. Finally, this paper figure out the building character processes establish since preparation of curriculum, learning processes and evaluation. These three processes are implemented in the formal and informal learning process.
\end{abstract}

Keywords: Character Education, Pesantren Education, Character Building

\section{PENDAHULUAN}

Pesantren merupakan lembaga pendidikan Islam di Indonesia yang berfokus pada pendidikan agama islam dan mengamalkannya sebagai pedoman hidup keseharian dengan menekankan pentingnya moral dalam hidup bermasyarakat (Fadli, 2012; Wekke \& Hamid, 2013). Oleh karenanya pesantren diidentikkan dengan produk orisinil dari agama islam dan adat. Pesantren sekaligus juga merupakan pendidikan tertua yang menjadi akar sejarah pendidikan yang berkontribusi besar terhadap pendidikan di Indonesia (Mar'ati, 2014; Masqon, 2011). Keberadaan pesantren diperkirakan mulai ada seiring dengan masuknya islam ke Indonesia. Terdapat dua pendapat tentang asal-usul pesantren di Indonesia; yaitu pertama berasal dari India berdasarkan bentuk dan sistemnya. Kedua Berasal dari tradisi Islam, yaitu tradisi tarekat. Pendapat kedua ini mengacu asumsi bahwa penyiaran Islam di Indonesia pada awalnya melalui tarekat (Fadli, 2012).

Berdasakan data Sistem Informasi dan Manajemen Pendidikan Dirjen Pendidikan Islam Indonesia, pesantren di Indonesia berjumlah 14.361 buah. Sebanyak 1.381 pesantren berada di pulau Sumatra, 11.664 pesantren berada di pulau Jawa, 336 pesantren berada di pulau Bali \& Nusa Tenggara, 294 pesantren berada di pulau Kalimantan, 661 pesantren berada di Celebes dan 25 pesantren berada di pulau Papua (Masqon, 2011). Wahjoetomo (1997) membedakan pesantren di Indonesia menjadi tiga tipologi meskipun sulit untuk membedakan secara ekstrim. Tipe tersebut adalah salafiyah (tradisional), khalafiyah (modern) dan terpadu. 
Pesantren salafiyah adalah pesantren yang hanya mengajarkan ilmu-ilmu agama Islam melalui kitab-kiab klasik yang ditulis oleh para ulama terdahulu dengan metode pengajaran bandongan, sorogan, hafalan dan musyawarah. Pesantren tipe Khalafiyah adalah tipe pesantren modern, yang di dalamnya mengajarkan ilmu-ilmu agama Islam dan ilmu-ilmu pengetahuan umum, tetapi masih tetap mengajarkan kitab-kitab klasik seperti pesantren salafiyah (Zuhriy, 2011).

Dalam perkembangannya, pesantren telah membangun corak dan sistem pendidikan tersendiri sesuai dengan kultur dimana pesantren tersebut ada. Namun, secara keseluruhan sistem pendidikan pesantren berbeda dengan dua sistem pendidikan lainnya di Indonesia, yaitu madrasah dan sekolah (Masqon, 2011). Dalam beberapa waktu belakangan, sistem pendidikan pesantren dipercaya sebagai sistem pendidikan yang mampu mewujudkan tujuan pendidikan nasional yang tidak tidak mampu sepenuhnya diwujudkan oleh sistem pendidikan sekolah dan madrasah. Pendidikan nasional dalam UU sistem pendidikan nasional yaitu berkembangnya potensi peserta didik agar menjadi manusia yang beriman dan bertakwa kepada Tuhan Yang Maha Esa, berakhlak mulia, sehat, berilmu, cakap, kreatif, mandiri, dan menjadi warga negara yang demokratis serta bertanggung jawab. Untuk mencapai tujuan tersebut, berkembang wacana pendidikan karakter sejak satu dekade terakhir (Izfanna \& Hisyam, 2012), yaitu sebuah upaya membimbing perilaku manusia menuju nilai-nilai kehidupan (Rukiyati \& Purwastuti, 2016).

Karakter (akhlak) merupakan keadaan internal, ciri-ciri, sifat-sifat atau kemampuan yang dimiliki individu yang memimpin mereka untuk melakukan perilaku tanpa pemikiran dan pertimbangan pertimbangan dan telah berkembang menjadi kebiasaan dimana nilai-nilainya diletakkan pada ajaran Islam. Perilaku tersebut mencakup kualitas internal dan eksternal manusia dan didasarkan pada perspektif bahwa perilaku berhubungan erat dengan jiwa dan niatnya (Izfanna \& Hisyam, 2012). Di Amerika Serikat, pendidikan karakter berhubungan dengan upaya sekolah untuk melaksanakan program pendidikan di bidang nilai-nilai moral, etika dan pendidikan kewarganegaraan. Character Education Partnership mendefenisikan pendidikan karakter sebagai upaya yang disengaja oleh sekolah, keluarga, dan masyarakat untuk membantu kaum muda memahami, peduli, dan bertindak berdasarkan nilai-nilai utama etika (Lickona, 1996).

Banyak literature dan studi yang telah dilakukan baik oleh peneliti maupun mahasiswa yang berhubungan dengan pendidikan karakter ataupun pendidikan karakter di Pesantren. Namun, secara garis besar terdapat dua kategori tulisan yang membahas tentang pendidikan karakter. Kategori pertama adalah artikel yang bersifat normatif yang diramu dari penelusuran literature untuk kemudian penulis membuat kesimpulan darinya. Berdasarkan penelusuran literatur dan kesimpulan tersebut penulis kemudian menyumbangkan gagasan. Tulisan-tulisan dalam terma ini bisa ditelusuri antara lain dalam tulisan tentang konsep dan aplikasi yang berhubungan dengan pendidikan karakter di pesantren (Mudlofir, 2013), ide dan gagasan pendidikan karakter di pesantren (Mar'ati, 2014) dan gagasan model-model pendidikan karakter (Perdana, 2015). Tulisan terakhir, meskipun bersumber dari penelitian lapangan, namun lebih dominan membahas gagasan.

Kategori kedua, tulisan yang bersumber dari penelitian lapangan dengan menjadikan pesantren tertentu sebagai subjek peelitian. Tulisan yang bersumber dari studi lapangan ini antara lain terlihat dari tulisan tentang pendidikan karakter di Pondok Pesantren Darunnajah (Izfanna \& Hisyam, 2012), pendidikan karakter di Pondok Pesantren Ihyaul Ulum Gilang Babat dan Pondok Pesantren Langitan Widang Tuban (Zuhriy, 2011) dan juga studi yang dilakukan di Pondok Pesantren Darul Falah (Sumardi, 2012) dan beberapa pondok pesantren di Pulau Sumatera (Perdana, 2015). Namun, dua studi terakhir tidak banyak menguraikan tentang praktek pendidikan karakter di pesantren lokasi studi, namun lebih banyak menjadikan lokasi studi sebagai bahan meramu gagasan dari gugusan gagasan yang sudah tersedia dalam berbagai literatur.

Zuhriy dan Sumardi berkesimpulan dari studinya bahwa pendidikan karakter di pesantren salafiah dilaksanakan melalui keteladanan yang diberikan oleh kiyai dan para guru. (Sumardi, 2012; Zuhriy, 2011). Intensitas interaksi antar santri, pengurus, aturan dan tata tertib dalam bentuk peraturan santri, kebijakan atas dasar elaborasi dari kerso dalem (kehendak) Kiai serta visi dan misi pesantren adalah faktor yang mendukung keberhasilan pendidikan karakter (Zuhriy, 2011). Pembentukan karakter tidak dititipkan dalam tiap pelajaran yang diberikan tapi dilakukan secara holistik dengan menerapkan aturan dan keteladanan. Pendidikan holistik membentuk manusia secara utuh (holistik) yang berkarakter, yaitu mengembangkan aspek/potensi spiritual, potensi emosional, potensi intelektual (intelegensi \& kreativitas), potensi sosial, 
dan potensi jasmani siswa secara optimal (Perdana, 2015). Pondok Pesantren Darunnajah mengadopsi secara komprehensi pendekatan pendidikan karakter berbasis nilai-nilai islam sebagai filosofi utama, visi, misi prinsip dasar karakter serta karakter utama lain yang dikembangkan dan diperkuat melalui tiga metode implementasi pendidikan karakter, yaitu pengetahuan, persyaratan dan praktek (Izfanna \& Hisyam, 2012).

Selain dua kategori di atas, terdapat kecenderungan studi pendidikan karakter lebih dominan dilakukan di pesantren-pesantren di Pulau Jawa. Hanya studi Sumardi dan Perdana yang dilakukan di Pulau Sumatera. Meskipun demikian, studi Sumardi di Pesantren di Lampung dilakukan di pesantren dengan kultur Jawa, sehingga di karakter pesantren Jawa kuat mempengaruhi. Kemudian Studi Perdana, dilakukan di beberapa propinsi di Pulau Sumatera tanpa melakukan spesifikasi pesantren yang diteliti secara tegas sesuai dengan tipologi pesantren yang ada. Artikel ini membahas tentang pola yang digunakan oleh pesantren di Sumatera Barat dalam membentuk karakter cerdas, pekerja keras dan ikhlas. Pembatasan tiga karakter ini dilakukan untuk menfokuskan bahasan pada tujuan utama pendidikan menurut Tan Malaka, yaitu mempertajam kecerdasan, memperkukuh kemauan serta memperhalus perasaan (Malaka, 2014). Selain itu, pembahsan juga akan difokuskan pada pesantren beraliran Tarbiyah. Pembatasan ini dilakukan karena karakteristik pesantren di Sumatera Barat berbeda antara satu sama lain, namun pesantren Tarbiyah memiliki karakteristik yang relatif sama di seluruh Sumatera Barat.

\section{METODE}

Artikel ini ditulis berdasarkan penyelidikan dengan pendekatan kualitatif bertipe deskriptif. Data penyelidikan dikumpulkan dengan dua cara. Pertama, data dikumpulkan secara normatif melalui penelusuran terhadap literatur yang membahas tentang pendidikan karakter dan pesantren melalui publikasi ilmiah yang tersedia di berbagai jurnal. Hasil penelusuran tersebut kemudian dikategorisasi dan dijadikan referensi penulisan sesuai dengan tujuan penulisan. Kedua, data dikumpulkan secara empiris di beberapa sekolah tarbiyah di Sumatera Barat dan melalui wawancara dengan guru, pimpinan dan mantan santri yang pernah belajar di pesantren tarbiyah. Wawancara tersebut berlangsung dalam berbagai diskusi dengan mereka sejalan dengan berbagai kegiatan yang melibatkan pesantren-pesantren tarbiyah. Selain itu, pengalaman penulis belajar selama 7 (tujuh) tahun di Pondok Pesantren Ashabul Yamin merupakan sumber yang paling penting dalam penulisan artikel ini.

\section{PENDIDIKAN ISLAM DAN PESANTREN DI SUMATERA BARAT}

Pesantren di Sumatera Barat tidak dapat dipisahkan dari surau sebagai cikal bakalnya. Pada mulanya, pendidikan di Sumatera Barata dengan sistem kebudayaan Minangkabau berpusat di surau. Surau di Minangkabau adalah kepunyaan suku atau kaum sebagai pelengkap rumah gadang yang berfungsi sebagai tempat bertemu, berkumpul, rapat, belajar adat, belajar silat dan tempat tidur bagi anak laki-laki yang telah masuk aqil baligh dan orang tua yang sudah uzur (Moenada, 2011; Sabarudin, 2015). Pada masa awal kedatangan Islam ke Sumatera Barat, fungsi surau sebagai tempat belajar agama islam. Fungsi keagamaan surau semakin penting, tidak hanya sebagai tempat anak-anak dan remaja memperoleh pengetahuan dasar keagamaan, tetapi juga sebagai lembaga pendidikan Islam yang lengkap (Moenada, 2011). Surau kemudian berubah bentuk menjadi dua kategori, yaitu surau gadang (surau besar) dan surau ketek (surau kecil). Surau gadang mampu menampung 80-100 murid yang sengaja didirikan sebagai tempat pendidikan agama dalam pengertian luas dan menjadi pusat aktivitas (central activity) pendidikan agama. Dalam pengertian yang lebih luas surau gadang dapat disamakan dengan pesantren yang menjadi pusat belajar agama di Jawa. Sedangkan surau ketek (kecil), adalah surau yang hanya menampung 20 orang murid. Surau ketek ini dapat disamakan dengan langgar atau mushalla (Natsir, 2012).

Peranan surau sebagai lembaga pendidikan di Minangkabau mulai mengalami kemunduran sejak awal abad XX, yaitu ketika masyarakat Islam Minangkabau berada dalam situasi yang semakin terjepit karena tekanan ekonomi dan politik kolonial Belanda dan adanya ide-ide pembaharuan keagamaan. Pada saat bersamaan pemerintah Belanda menjalankan ethischepolitiek. Belanda mendirikan sekolah-sekolah di Sumatera Barat dengan sistem pendidikan modern. Sekolah-sekolah sekuler didirikan pada awal pertengahan 1840-an atas inisiatif individual petinggi Belanda. Sekolah yang mula-mula dibangun di pusat-pusat administratif 
regional di dataran tinggi dan di daerah pusat produksi kopi di kawasan perbukitan. Tujuan pendirian sekolah lebih utama untuk kepentingan kolonial ketimbang alasan pendidikan itu sendiri. Kepentingan tersebut adalah untuk pengembangan sistem birokrasi yang diperlukan dalam sistem tanam paksa kopi dan memenuhi kebutuhan pemerintah mereka (Graves, 2007; Hadler, 2010; Sabarudin, 2015). Sejumlah orang Minangkabau yang tertarik pada pendidikan sekuler, mereka mula-mula belajar dengan magang secara pribadi pada kantor-kantor dagang pemerintah atau dalam birokrasi (Graves, 2007). Anak-anak pribumi kemudian mulai di sekolah Belanda (Moenada, 2011) dan di sekolah Belanda mereka diperkenalkan dengan ilmu sosial dan ilmu alam dan tidak menekankan sama sekali pada pengetahuan agama. Selain tujuan pendidikan, metode pembelajaran mereka juga berbeda. Di sekolah Belanda, siswa-siswa belajar dengan menggunakan meja dan kursi, dan tingkat kelas. Sementara sekolah tradisional Minangkabau yang bertransformasi dari surau, menggunakan metode halaqah dan tidak menggunakan sistem kelas.

Sistem pendidikan yang dikembangkan oleh kolonial Belanda terus merobah pola dan sistem pendidikan islam di Minangkabau. Dengan dikembangkannya sistem pendidikan sekolah yang mengajarkan peserta didik menulis, membaca, berhitung dan berfikir kritis, sistem pendidikan islam tradisional dengan sistem halaqah yang lebih menekankan pada hafalan terhadap ilmu mulai ditinggalkan oleh pemuda-pemuda di Minangkabau. Mencermati perkembangan sistem pendidikan tersebut, adalah ulama besar Mekkah asal Minangkabau Syeikh Ahmad Khatib Al- Minangkabaui kemudian melakukan pembaharuan sistem pendidikan surau yang dianggap tertinggal dari sistem pendidikan sekuler Belanda. Pembaharuan dilakukan melalui murid-muridnya yang belajar langsung dengannya ke Mekah. Pembaharuan tersebut menurut Gazalba (1983) menghasilkan pendidikan surau menjadi madrasah yang klasikal dan tidak lagi berhalaqah, serta terjadi perombakan-perombakan dalam kurikulum pendidikan (Rahman 2015).

Dari beberapa corak lembaga pendidikan yang ditawarkan ada beberapa ciri yang berbeda, hal ini dapat dikelompokkan kepada tiga corak; pertama, corak yang lebih mengadopsi pola pendidikan Kolonial Belanda. Model ini diwakili oleh Abdullah Ahmad yang mendirikan pendidikan modern ala sekolah. Kedua, corak yang mempertahankan ciri khas surau dengan mengadakan pembaharuan/modernisasi yang berkiblat ke Timur Tengah. Model ini diwakili oleh Syekh Abdul Karim Amrullah; mereka mendirikan pendidikan modern ala madrasah. Ketiga, pembaharuan pendidikan yang beorientasi kepada kebutuhan masyarakat (social demand). Model ini diwakili oleh Zainuddin Labay el-Yunusi dan Rahmah elYunusiah. Mereka mendirikan pendidikan modern ala sekolah Kejuruan (takhassus), walaupun belum sepenuhnya (Rahman, 2015). Corak pendidikan dalam rangka modernisasi pendidikan dapat dilihat dalam tabel di bawah ini:

Tabel 1Corak Pendidikan dalam Rangka Modernisasi Pendidikan di Sumatera Barat

\begin{tabular}{|c|c|c|c|c|}
\hline $\begin{array}{c}\text { Corak } \\
\text { Pendidikan } \\
\end{array}$ & $\begin{array}{c}\text { Lembaga } \\
\text { Pendidikan }\end{array}$ & $\begin{array}{l}\text { Tahun } \\
\text { Berdiri } \\
\end{array}$ & Pendiri & Keterangan \\
\hline $\begin{array}{l}\text { Pendidikan } \\
\text { Modern Ala } \\
\text { Sekolah }\end{array}$ & $\begin{array}{l}\text { Adabiyah } \\
\text { School }\end{array}$ & 1907 & Abdullah Ahmad & $\begin{array}{ll}- & \text { Menerapkan sistem klasikal } \\
\text { - } & \text { Integrasi kurikulum ilmu agama dan } \\
& \text { umum } \\
\text { - } & \text { Menggunakan metode debating club } \\
\text { - } & \text { Perlu sumber dana alternatif } \\
\end{array}$ \\
\hline \multirow[t]{2}{*}{$\begin{array}{l}\text { Pendidikan } \\
\text { Modern } \\
\text { Kejuruan }\end{array}$} & $\begin{array}{l}\text { Diniyah } \\
\text { School }\end{array}$ & 1915 & $\begin{array}{l}\text { Zainuddin Labay } \\
\text { el-Yunusi }\end{array}$ & $\begin{array}{ll}\text { - } & \text { Sistem pembelajaran bersifat klasikal } \\
\text { - } & \text { Kurikulum sudah teratur materi } \\
\text { pelajaran meliputi agama dan umum } \\
\text { - } \\
\text { Berorientasi output yang bermutu } \\
\text { baik bidang keagamaan maupun } \\
\text { umum }\end{array}$ \\
\hline & $\begin{array}{l}\text { Diniyah } \\
\text { Putri }\end{array}$ & 1923 & $\begin{array}{l}\text { Rahmah } \\
\text { Yunusiah }\end{array}$ & $\begin{array}{l}\text { Memiliki berbagai programpendidikan } \\
\text { baik umum maupun agama seperti } \\
\text { program pendidikan agama Islam, } \\
\text { program pendidikan khusus program } \\
\text { keterampilan, dan program pendidikan } \\
\text { bahasa Arab }\end{array}$ \\
\hline
\end{tabular}




\begin{tabular}{|c|c|c|c|c|}
\hline \multirow[t]{3}{*}{$\begin{array}{l}\text { Pendidikan } \\
\text { Modern ala } \\
\text { Madrasah }\end{array}$} & $\begin{array}{l}\text { Sumatera } \\
\text { Thawalib }\end{array}$ & 1918 & $\begin{array}{l}\text { Syekh Haji Abdul } \\
\text { Karim Amrullah }\end{array}$ & $\begin{array}{l}\text { Awalnya merupakan sebuah organisasi } \\
\text { yang bergerak dalambidang pendidikan } \\
\text { yang meliputi dua lembaga yaitu } \\
\text { Sumatera Thawalib di Padang Panjang } \\
\text { dan Di Parabek. Namun Karena } \\
\text { perkembangan politik, maka pengaruh } \\
\text { politik juga masuk ke lembaga ini }\end{array}$ \\
\hline & $\begin{array}{l}\text { Normal } \\
\text { Islam }\end{array}$ & $\begin{array}{l}1931- \\
1946\end{array}$ & Mahmud Yunus & $\begin{array}{l}\text { Menggunakan metode moderndalam } \\
\text { melaksanakan kegiatan belajar seperti } \\
\text { pemakaian papan tulis, meja, kursi } \\
\text { tempat duduk untuk para siswa }\end{array}$ \\
\hline & $\begin{array}{l}\text { Madrasah } \\
\text { Tarbiyah }\end{array}$ & 1928 & $\begin{array}{l}\text { Syekh Sulaiman } \\
\text { Ar-Rasuly, Syeikh } \\
\text { Jamil Jaho, } \\
\text { Syeikh Abbas, } \\
\text { Syeikh Abdul } \\
\text { Wahid, M. Arifin } \\
\text { Batu Hampar, } \\
\text { Syeikh } \\
\text { Makhudum, } \\
\text { Syeikh M. Yunus. }\end{array}$ & $\begin{array}{l}\text { MTI didirikan berbentuk organisasi yang } \\
\text { betujuan untuk memajukan pendidikan } \\
\text { dan pengajaran Islam }\end{array}$ \\
\hline
\end{tabular}

Pada tahun 1920-an dan 1930-an banyak tokoh perguruan islam tradisional menyesuaikan sekolahnya dengan perkembangan zaman modern dan jumlahnya pun meningkat. Bahkan sejak 1918 Syeikh Siradjuddin Abbas dari Padang Lawas, yang menyadari adanya tantangan dari aliran pemikiran Islam modern, sudah mulai memperkenalkan metode pengajaran modern di perguruannya meski tetap mempertahankan paham keagamaan tradisionalnya. Pada tahun 1928 beliau membujuk tokoh-tokoh tradisionalis lainnya, yiatu Syeikh Sulaiman Arrasuli dari Canduang dan Syeikh Muhammad Jamil Jaho dari Padang Panjang agar melakukan reorganisasi dan mengkoordinasikan sekolah-sekolah mereka. Dua tahun kemudian, ulama-ulama tradisional yang dipelopori oleh Syeikh Sulaiman Ar-Rasuli mendirikan Persatuan Tarbiyah Islamiyah, sebuah organisasi sosial tempat berkumpul sekolah islam tradisional. Sampai akhir tahun 1930-an ada kira-kira 127 sekolah tradisional ini dengan jumlah murid sekitar 120 ribu (Kahin, 2005). Hingga sekarang, sekolah-sekolah tarbiyah tersebut masih terus menyelenggarakan pendidikan agama dengan memadukan antara pendidikan agama dan umum untuk memenuhi tuntutan kurikulum nasional.

\section{POLA PENDIDIKAN KARAKTER PESANTREN DI SUMATERA BARAT}

Pasca modernisasi pendidikan di Sumatera Barat, selain mengajarkan pengajaran agama, sekolah-sekolah juga memberikan pelajaran sejarah, geografi, bahasa asing dan matematika. Akan tetapi mata pelajaran umum tersebut umumnya disesuaikan dengan kebutuhan masyarakat Sumatera Barat, dan guru-gurunya selalu berusaha membuat sekolah-sekolah tersebut berbeda dari sekolah-sekolah pemerintah (Kahin, 2005). Tidak terkecuali itu, sekolah-sekolah Tarbiyah yang tersebar di seluruh Sumatera Barat juga mengajarkan pelajaran umum tersebut namun hanya sebatas kebutuhan terhadapnya semata. Penyesuaian dengan kebutuhan tersebut tercermin dalam kurikulum pendidikan pesantren tarbiyah yang mengalokasikan jam pelajaran pada mata pelajaran agama. Pelajaran-pelajaran umum meyoritas hanya diajarkan untuk menjawab kebutuhan ujian nasional agar para santri dapat mengikuti ujian dan mendapatkan ijazah untuk melanjutkan pendidikan mereka ke jenjang yang lebih tinggi (wawancara Pimpinan Pesantren Tarbiyah). Dalam kegiatan belajar, tidak jarang mata pelajaran umum yang kosong karena guru berhalangan hadir diganti dengan pelajaran agama.

Mata pelajaran agama yang diajarkan di pesantren tarbiyah di Sumatera Barat mencakup semua materi untuk kebutuhan hidup sehari-hari dan bekal hidup di akhirat. Mata pelajaran tersebut antara lain adalah fiqh, tasawuf, tafsir, hadist, ushul fiqh, tauhid dan lain-lain. Kemudian, sebagai alat untuk mempelajri kitab- 
kitab referensi untuk mempelajari ilmu tersebut diajarkan ilmu nahwu, sharaf, mantiq, balaghah, ushul fiqh yang akrab dikenal dengan ilmu alat, yaitu ilmu untuk mempelajari kitab-kitab referensi. Semua materi pelajaran agama bersumber dari kitab-kitab berbahasa Arab. Meskipun tersedia buku-buku paket berbahasa Indonesia yang biasa digunakan di madrasah, pesantren tarbiyah tidak menggunakannya sebagai referensi. Materi-materi pelajaran tersebut yang kemudian digunakan dalam proses pembentukan karakter santri di pesantren tarbiyah secara umum.

Karakter merupakan konstruksi psikologis, oleh karenanya luaran pendidikan karakter yang efektif adalah pengembangan psikologis pelajar (Berkowitz \& Bier, 2005). Di Pesantren tarbiyah, proses pembelajaran meskipun tidak secara spesifik menyebut istilah pendidikan karkter- berorientasi pada pembentukan attitude santri yang di Indonesia sejak satu dekade terakhir popular dengan istilah pendidikan karakter. Ada banyak karakter yang dibentuk oleh sistem pendidikan yang dilaksanakan oleh pesantren secara umum, namun di pasantren-pesantren tarbiyah terdapat tiga karakter utama yang terbentuk dan manonjol pada santri. Karakter tersebut adalah cerdas, kerja keras dan ikhlas. Masing-masing proses pembentukan karakter tersebut dapat diuraikan sebagai berikut.

\section{Pembentukan Karakter Cerdas}

Indikator manusia cerdas adalah manusia yang aktif, objektif, analitis, aspiratif, kreatif dan inovatif, dinamis dan antisipatif, berpikiran terbuka dan maju serta mencari solusi. (Prayitno, 2011). Dalam proses pendidikan di pesantren, seluruh santri diorientasikan untuk menjadi manusia cerdas tersebut. Untuk menjadikan santri berkarakter cerdas, proses belajar berlangsung secara dialogis dimana ruang diskusi dan debat dengan guru dan sesama santri sangat terbuka luas. Tidak hanya pada level diskusi, perdebatan dan perbedaan pendapat antara sesama santri atau santri dengan guru adalah hal yang biasa dalam proses belajar. Bahkan, tidak jarang santri-santri mempelajari mata pelajaran tertentu (terutama ilmu-ilmu alat) dengan guru lain sebelum belajar di kelas bersama guru pengampu mata pelajaran. Di kelas kemudian diskusi dan perdebatan berlangsung dalam membahas i'rab matan (gramatikal) kitab-kitab yang menjadi referensi. Dalam proses belajar yang seperti demikian, guru juga tidak jarang mempersiapkan bahan pelajaran yang akan diajarkan sebelum masuk ke dalam kelas. Artinya, guru menyediakan diri secara terbuka untuk berdiskusi dan berdebat dengan santri. Proses diskusi dan perdebatan akan berkahir dengan menyamakan sudut pandang untuk mendudukkan i'rab matan (gramatikal) teks bacaaan. Selain dalam proses belajar, pembentukan karakter cerdas dilakukan dengan memberikan ruang kepada seluruh santri ntuk melakukan kegiatan ekstrakurikuler seperti OSIS, olah raga, Pramuka, Seni dan kegiatan lainnya. Kegiatan-kegiatan ekstrakurikuler lain seperti muhadharah, diskusi, debat, perlombaan dan kegiatan lain diberikan ruang dan dukungan oleh sekolah.

\section{Pembentukan Karakter Pekerja Keras}

Pekerja keras secara umum merupakan sebutan bagi orang yang berciri ulet, gigih, rajin, pantang menyerah, tidak mudah putus asa dan lainnya dalam bekerja. Karakter pekerja keras pada pelajar dapat difahami sebagai karakter yang gigih dan tangguh. Ketangguhan pada pelajar antara lain dapat dilihat dari ketahanan mereka dalam menghadapi ujian selama proses belajar yang tercermin dalam kemandirian mereka. Di pesantren tarbiyah, proses pembentukan karakter pekerja keras sudah dilakukan sejak santri datang untuk belajar. Ujian tersebut terutama bagi santri yang tinggal di asrama atau tinggal di rumah penduduk di sekitar sekolah (mayoritas pesantren tarbiyah di Sumatera Barat tidak mewajibakan santri tinggal di asrama). Dengan tinggal di asrama atau di rumah penduduk di sekitar sekolah, mereka harus berpisah dengan orang tua sejak rata-rata berusia 11-13 tahun. Di asrama atau di rumah penduduk mereka hidup mandiri dengan mengerjakan seluruh kepentingan mereka secara sendiri-sendiri. Pembentukan karakter pekerja keras juga berlangsung dari proses belajar yang sepanjang waktu dengan jumlah mata pelajaran yang dua kali lipat dibanding sekolah umum. 


\section{Pembentukan Karakter Ihklas}

Kata ikhlas dapat diartikan dengan jujur, tulus, rela, kemurnian atau kebersihan atau kesucian atau ketauhidan. Dengan demikian, orang ikhlas adalah orang yang melakukan perbuatan (beramal) dengan kejujuran, ketulusan, kerelaan dan kemurnian serta kebersihan hati karena Allah SWT, tanpa dipengaruhi oleh hal-hal lain, seperti keinginan untuk mendapatkan keistimewaan, posisi atau kedudukan atau dipuji dan lain sebagainya (Hasiah, 2013). Proses pembentukan karakter ikhlas pada santri dilakukan dengan penanaman nilai-nilai yang mengacu pada kaarkter ihklas tersebut. Di pesantren tarbiyah, proses penanaman nilai-nilai tersebut dilakukan melalui kurikulum dan proses belajar. Seperti disinggung di atas, meskipun kurikulum pesantren tarbiyah mengombinasikan antara mata pelajaran agama dan mata pelajaran umum, namun alokasi waktu belajar lebih banyak dialokasikan untuk mata pelajaran agama, yaitu $70 \%$ dari keseluruhan jam pelajaran yang tersedia. Dengan alokasi seperti demikian, maka pengetahuan ukhrawi yang berorientasi pada nilai lebih dominan. Dalam proses belajar santri diorientasikan kepada kecintaan pada ilmu pengetahuan, dalam artian tujuan belajar adalah untuk pengetahuan, bukan untuk mendapatkan nilai yang baik dalam ujian. Dalam proses belajar, santri ditekankan untuk memahami materi pelajaran, bukan menghapal berbagai konsep dan defenisi yang ada untuk diujikan. Pola pendekatan ini menjadikan santri tidak berfikir mengikuti pelajaran hanya sebatas mengikuti ujian pada akhir semester seperti pola umum yang berlaku pada siswa-siswa di sekolah umum.

\section{KESIMPULAN}

Karakter tidak dapat dibangun dalam satu waktu, tetapi terus menjadi proses yang komprehensif. Model yang paling efektif untuk implementasi pembentukan karakter adalah melalui pendekatan komprehensif yang mengintegrasikan semua aspek kehidupan sekolah sebagaimana dikatakan oleh Berkowitz (2005) bahwa pendidikan karakter yang efektif adalah transformasi budaya dan kehidupan sekolah (Izfanna \& Hisyam, 2012). Dalam hal ini, Pesantren Tarbiyah di Sumatera Barat telah mengintegrasikan antara materi pelajaran dengan proses kehidupan sehari-hari santri di sekolah dan lingkungan sekolah dalam membentuk karakter santri, terutama karakter cerdas, pekerja keras dan ikhlas. Proses pembentukan ketiga karakter tersebut dilakukan sepanjang santri belajar secara formal di kelas dan informal di luar kelas. Proses pembentukan karakter juga dilakukan dalam kehidupan sehari-hari santri di lingkungan masyarakat dimana mereka tinggal dan berinteraksi. Sehingga, proses pembentukan karakter tidak hanya dilakukan dalam proses belajar di kelas, akan tetapi juga dalam kegiatan ekstrakurikuler dan dalam kehidupan sehari-hari. Berdasarkan proses yang dilakukan pesantren, maka tidak dapat dibantah bahwa proses pembentukan karakter merupakan proses berkelanjutan dan terintegrasi yang harus dilakukan di sekolah dan lingkungan dimana proses belajar berlangsung. Oleh karenanya, lingkungan dimana proses belajar berlangsung sangat menentukan pada karakter santri.

\section{DAFTAR PUSTAKA}

Berkowitz, M. W., \& Bier, M. (2005). What Works In Character Education: A Research-Driven Guide For Educators. Washington DC.

Fadli, A. (2012). Pesantren: Sejarah dan Perkembangannya. EL-HIKAM: Jurnal Pendidikan Dan Kajian Keislaman, V(1), 29-42.

Graves, E. (2007). Asal-Usul Elite Minangkabau Modern; Respon Terhadap Kolonial Belanda Abad XIX/XX. Jakarta: Yayasan Obor Indonesia.

Hadler, J. (2010). Sengketa Tiada Putus: Matriarkat, Reformisme Agama, dan Kolonialisme di Minangkabau. Jakarta: Freedom Institute.

Hasiah. (2013). Peranan Ikhlas dalam perspektif Al-Quran. Darul Ilmi, 1(2), 21-44. 
Izfanna, D., \& Hisyam, N. A. (2012). A Comprehensive Approach in Developing Akhlaq: A Case Study on the Implementation of Character Education at Pondok Pesantren Darunnajah. Multicultural Education \& Technology Journal, 6(2), 77-86. http://doi.org/10.1108/17504971211236254

Kahin, A. (2005). Dari Pemberontakan ke Integrasi; Sumatera Barat dan Politik Indonesia 1926-1998. Jakarta: Yayasan Obor Indonesia.

Lickona, T. (1996). Eleven Principles of Effective Character Education. Journal of Moral Education, 25(1), 93-100. http://doi.org/10.1080/0305724960250110

Malaka, T. (2014). MADILOG; Materialisme, Dialektika dan Logika. Jakarta: Pustaka Narasi.

Mar'ati, R. (2014). Pesantren Sebagai Basis Pendidikan Karakter; Tinjauan Psikologis. Al-Murabbi, 1(1), 1-15.

Masqon, D. (2011). Dynamic of Pondok Pesantren as Indegenous Islamic Education Centre In Indonesia. Jurnal Tsaqafah, 7(1), 155-168.

Moenada, M. S. (2011). Surau dan modernisasi pendidikan di masa hindia belanda. Jurnal Sosial Budaya, $8(1), 40-54$.

Mudlofir, A. (2013). Pendidikan Karakter: Konsep dan Aktualisasinya dalam Sistem Pendidikan Islam. Nadwa; Jurnal Pendidikan Islam, 7(2), 229-246.

Natsir, M. (2012). Peranan Surau Sebagai Lembaga Pendidikan Islam Tradisional Di Padang Pariaman Sumatera Barat (Surau Syeikh Burhanuddin). PEDAGOGI | Jurnal Ilmiah Ilmu Pendidikan Volume XII No.2 November 2012, XII(2), 39-46.

Perdana, N. S. (2015). Character Education Model Based on Education in Islamic Boarding School. Edutech, Tahun 14,(3), 402-422.

Prayitno. (2011). Pendidikan Sukses dan Bermutu Menghadapi Masa Depan. In S. Ahmad, H. M. D. Basir, T. Fauzi, N. Kesumawati, S. Eddy, Q. Z. Marhani, \& D. Basuki (Eds.), Prosiding Seminar Nasional Pendidikan. (pp. 1-15). Palembang: Universitas PGRI Palembang.

Rahman, R. (2015). Modernisasi Pendidikan Islam Awal Abad 20: Studi Kasus di Sumatera Barat. Jurnal Humanis, XIV(2), 174-182. http://doi.org/10.1017/CBO9781107415324.004

Rukiyati, \& Purwastuti, L. A. (2016). Model Pendidikan Karakter Berbasis Kearifan lokal Pada Sekolah Dasar di Bantul Yogyakarta. Jurrnal Pendidikan Karakter, VI(1), 130-142.

Sabarudin, M. (2015). Pola dan Kebijakan Pendidikan Islam Masa Awal dan Sebelum Kemerdekaan. Jurnal Tarbiya, 1 Nomor 1, 139-174.

Sumardi, K. (2012). Potret Pendidikan Karakter di Pondok Pesantren Salafiah. Jurnal Pendidikan Karakter, Tahun II(3), 280-292.

Wekke, I. S., \& Hamid, S. (2013). Technology on Language Teaching and Learning: A Research on Indonesian Pesantren. Procedia - Social and Behavioral Sciences, 83, 585-589. http://doi.org/10.1016/j.sbspro.2013.06.111

Zuhriy, M. S. (2011). Budaya Pesantren dan Pendidikan Karakter Pada Pondok Pesantren Salaf. Walisongo, 19(November 2011), 287-310. 